\title{
Drowning in good ideas
}

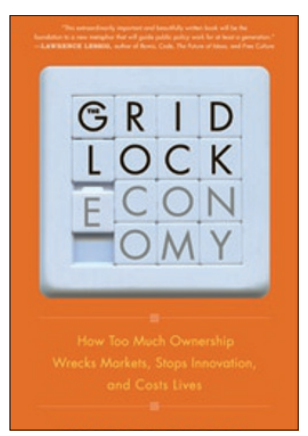

\section{The Gridlock Economy: How Too Much Ownership Wrecks Markets, Stops Innovation and Costs Lives \\ By Michael Heller}

Basic Books, 2008

304 pages, hardcover, $\$ 26.00$

ISBN-13: 9780465029167

\section{Reviewed by Bruce Berman}

Ownership run amok is the focus of The Gridlock Economy. The book argues that strong invention rights have reached a point of diminishing returns and that patents frequently undermine business and social objectives and waste valuable resources. In what author Michael Heller says has become the "anti-commons," intellectual property (IP) rights are a burden-a thicket of often ill-granted exclusivity that serious innovators must contend with. The book describes how researchers and organizations wishing to cash in on their proprietary rights are causing some companies to abandon commercializing products that might save lives. "Imagine 20 or 200 [patent] owners," writes Heller. "If any one blocks the other, the resource is wasted. That's gridlock writ large - a hidden tragedy of the anti-commons." Hidden, he says, because "underuse is hard to spot" and because "innovators don't advertise the projects they abandon." Illegal tolls, he asserts, discourage travelers from making the journey. A research director at a pharmaceutical company is cited as someone who "could not figure out how to pay off all the patent owners and still have a good chance of earning a profit."

The Gridlock Economy states that parties are often unable to solve rights disputes and that laws need to be made less tolerant of poor-quality patents. That is an easy statement to make because when it comes to inventions and the rights that cover them, quality is less of an objective standard than an idea. The book is strong on assumptions about what's wrong with patents and their owners, and how they can be fixed by "tuning up" regulations, but it is weak on how businesses can and do coexist and how parties compete fairly, despite an often uneven playing field. Although negotiating a thicket of rights can be daunting, cooler heads frequently prevail and most solutions get to market in a timely manner.

Bruce Berman CEO of Brody Berman Associates, New York. His most recent book is From Assets to Profits: Competing for IP Value and Return. e-mail:bberman@brodyberman.com
For example, in 2004 alone, Johnson \& Johnson's rheumatoid arthritis drug Remicade (infliximab) generated $\$ 109$ million in patent royalties for New York University (NYU) on revenues of $\$ 2.15$ billion. Those figures are up substantially since then. To hedge risk, NYU sold the future royalties of Remicade in 2007 for $\$ 650$ million. Some 25 other licensors, many of them universities and smaller companies, are benefiting fractionally from developments associated with the drug.

Heller's main premise, that patents can serve as potential barriers to delivering necessary products, is not without merit. However, the book does not distinguish clearly enough between specific contributions, types of owners or industries. Who gets to decide which advances are more important than others? Sometimes what appears to be a minor contribution can be the key that unlocks a successful discovery. Heller may be overstating the case for the commons and understating the one for how the value of complex products can be more fairly divided. While darkness may be gathering over some IP rights and their holders, the sky is not falling.

Today, larger patent holders are finding they must accommodate multiple ownership interests to score with new products. This can be maddening for a business under pressure from shareholders or from long-suffering patients. But without the incentive provided by patents, there would far fewer products worth fighting over. The contributions of some developments are better understood today than a decade or two ago when, for example, patents were routinely and broadly granted on partial gene discoveries, potentially endangering research. Recently, the Association of Molecular Pathology urged an end to granting patents on single genes, sequences of genomes or correlations between genetic variations and biological states.

In a complex world with more rights, less time and increased competition, less clutter can sometimes provide greater benefits. But more rights are inevitable and patent value is context driven. Increased open innovation is being promoted by many high-tech companies, including IBM and Microsoft. They are not suggesting charitable intent but are seeking alternative models to monetize complex investments and generate new business streams. More tech and science companies are working together to set standards and share profits because it can make sense. But for collaboration to succeed, it must be a two-way street.

The argument deftly framed in The Gridlock Economy is timely. Incentive may be the wellspring of invention, but greed, contrary to what Gordon Gekko said in Wall Street, is not necessarily good. The book suggests that innovation and its powerful rights are resources that can be depleted and need to be managed responsibly for both investment and social return. Music rights collectives such as ASCAP have successfully negotiated broad copyright use agreements for a variety of composers, musicians and their works. It remains to be seen how many and which patent holders will find similar arrangements acceptable, or if they should. 